\title{
AN OVERVIEW OF THE ORGANIZATION OF THIS GUIDE
}

\section{Section A GENERAL WORKS}

I. General Bibliography of Bibliographies (A-1 to A-9)

II. Student Reference Guides (A-10 to A-19)

III. General Reference Guides (A-20 to A-25)

IV. General Subject Indexes of Books (A-30 to A-39)

V. General Encyclopedias (A-40 to A-49)

VI. Special Encyclopedias in Ancillary Fields (A-50 to A-75)

\section{Section B LIBRARIES}

I. Library Directories (B-1 to B-9)

II. Union Catalogs (B-10 to B-15)

III. Major Library Catalogs and Guides: North American Libraries (B-20 to B-39)

IV. Major Library Catalogues and Guides: British and Irish Libraries (B-40 to B-59)

V. Major Library Catalogs and Guides: Continental Libraries (B-60 to B-70)

\section{Section C RETROSPECTIVE AND CURRENT NATIONAL BIBLIOGRAPHY}

I. General Bibliographies and Guides (C-1)

II. British and Irish National Bibliography (C-3 to C-17)

III. United States National Bibliography (C-20 to C-30)

IV. French National Bibliography (C-50 to C-57)

V. German National Bibliography (C-60 to C-68)

VI. Italian National Bibliography (C-71 to C-74)

\section{Section D SERIAL PUBLICATIONS}

I. Bibliographical Guides and Indexes to Indexes (D-1 to D-7)

II. General Indexes: Periodicals (D-10 to D-19)

III. General Indexes: Newspapers (D-20 to D-23)

IV. General Indexes: Little Magazines (D-27 to D-29)

V. Periodical Bibliography (D-35)

VI. Newspaper Bibliography (D-40 to D-45)

VII. Retrospective Bibliography, Historical Studies, and Finding Lists (D-50 to D-80)

VIII. Union Lists of Serials (D-90 to D-99) 
DX. Directories of Current Periodicals (D-100 to D-104)

X. Catalogs of Books in Series (D-105 to D-107)

Section E MISCELLANY

I. Dissertations - General and National Lists (E-1 to E-19)

II. Dissertations-Subject Lists (National Literatures) (E-20 to E-26)

III. Dissertations—Subject Lists in Fields of English and American Literature (E-30 to E-40)

IV. Microforms (E-50 to E-57)

V. Reprints (E-60 to E-68)

VI. Reviews (E-70 to E-78)

VII. Indexes to Composite Volumes (E-80 to E-88)

VIII. Anonyma and Pseudonyma (E-90 to E-95)

D. Guides to Spoken Recordings (E-100 to E-106)

X. Guides to Films from Literary Works (E-110 to E-115)

\section{Section F HISTORY AND ANCILLAE TO HISTORICAL STUDY}

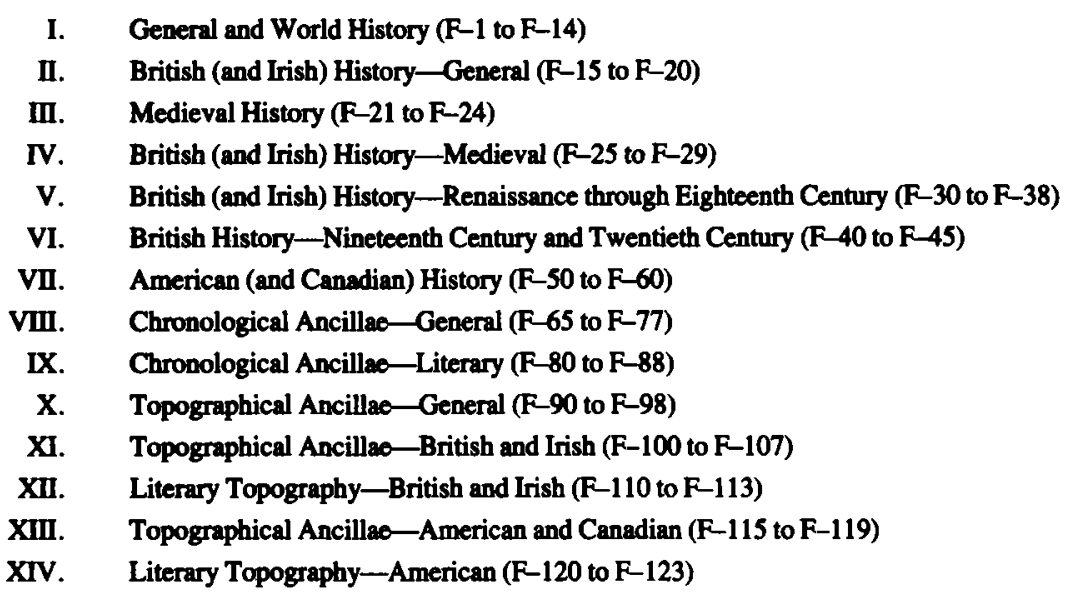

\section{Section G BIOGRAPHY AND BIOGRAPHICAL REFERENCES}

I. Indexes, Bibliographies, and General Works ( $G-1$ to $G-9)$

II. British Biography (G-10 to G-33)

III. American Biography (G-35 to G-47)

IV. Contemporary Biography (G-50 to G-58)

V. South American and Continental Biography (G-60 to G-71)

VI. Ancillae to Biographical Study (G-80 to G-87)

\section{Section H ARCHIVES AND MANUSCRIPTS}

I. General Guides to the Location, Study, and Use of Archives and Manuscripts (H-1 to H-9)

II. British Repositories (H-10 to H-19)

III. American Repositories (H-20 to H-29)

IV. The Manuscript Book (H-30 to H-34)

V. English Studies-Manuscripts (H-40 to $\mathrm{H}-48$ )

VI. American Studies-Manuscripts (H-50 to H-55)

VII. British Archives (H-60 to H-76)

VIII. American Archives (H-80 to H-85)

DX. Paleography (H-90 to H-125)

\section{Section I LANGUAGE, LINGUISTICS, AND PHLOLOGY}

I. Bibliographies-Language and Linguistics (1-1 to 1-17)

II. Bibliographies-Dictionaries (I-20 to I-27) 


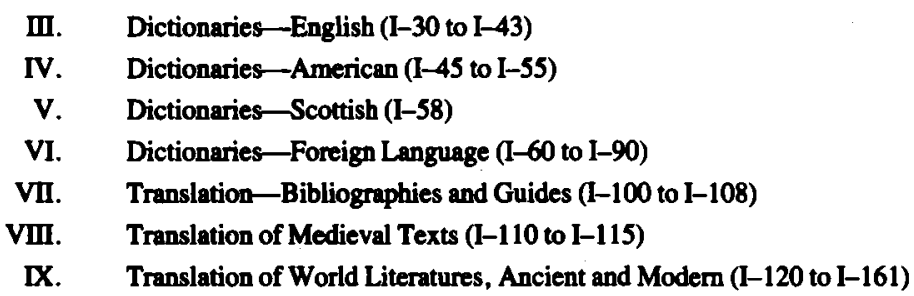

\section{Section $K$ LITERARY MATERIALS AND CONTEXTS}

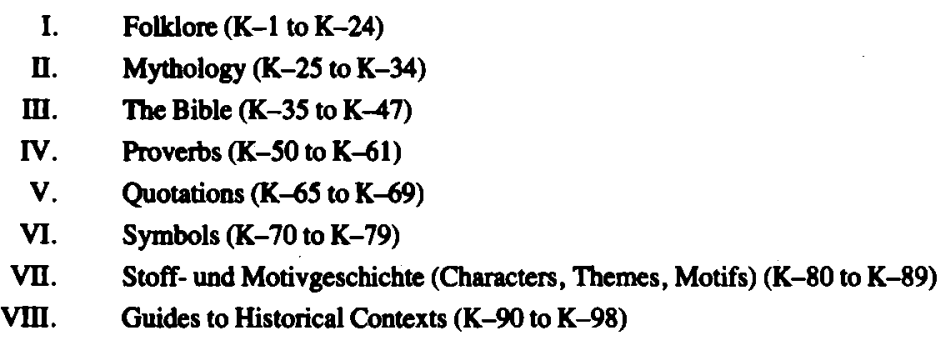

\section{Section L LITERATURE}

I. General and Comparative Literature (L-1 to $\mathrm{L}-10)$

II. General Literary Dictionaries, Terminologies, and Similar References (L-11 to L-33)

III. Classical Studies ( $\mathrm{L}-40$ to $\mathrm{L}-49)$

IV. Modern Languages and Literatures ( $L-50$ to $L-59$ )

V. Romance Languages and Literatures ( $\mathrm{L}-60$ to $\mathrm{L}-64)$

VI. French Language and Literature ( $\mathrm{L}-70$ to $\mathrm{L}-79)$

VII. Italian Language and Literature (L-80 to $\mathrm{L}-89)$

VIII. Hispanic, Hispanic-American, and Portuguese Languages and Literatures (L-90 to L-101)

IX. Germanic Languages and Literatures ( $\mathrm{L}-105$ to $\mathrm{L}-109)$

$X$. German Language and Literatures (L-110 to $\mathrm{L}-120)$

XI. Russian and Other Slavic Languages and Literatures (L-121 to L-129)

XII. African Languages and Literatures ( $\mathrm{L}-130$ to $\mathrm{L}-139)$

XIII. Oriental Languages and Literatures (L-140 to L-149)

XIV. Near Eastern Languages and Literatures (L-150 to L-153)

XV. Far Eastern Languages and Literatures (L-155 to L-169)

XVI. Children's Literature ( $L-170$ to $L-180)$

XVII. Women's Studies (L-181 to L-190)

XVIII. Women and Literature (L-191 to L-199)

XIX. Women and British Literature (L-200 to L-202)

XX. Women and American Literature ( $L-205$ to $L-208)$

\section{Section M ENGLISH LTTERATURE}
I. Bibliographies (M-1 to $\mathbf{M}-25)$
II. Literary Histories (M-30 to M-39)
III. Handbooks and Reader's Encyclopedias (M-40 to M-48)
IV. Biobibliographies (M-50 to M-58)
V. Guides to Individual Authors (M-60)
VI. Scottish Literature and Scottish Studies (M-70 to M-79)
VII. Anglo-lrish Literature and Irish Studies (M-80 to M-94)
VIII. Anglo-Welsh Literature and Welsh Studies (M-95 to M-99)
IX. Commonwealth Literature and World Literature Written in English (M-100 to M-109)
X. Africa (M-110 to M-119)
XI. Australia (M-120 to M-129)
XII. Canada (M-130 to $M-149)$ 
XIII. India (M-150 to $M-159)$

XIV. New Zealand and the South Pacific (M-160 to M-169)

XV. West Indies (M-172 to M-179)

Section N MEDIEVAL LTERATURE
I. General (N-1 to $\mathrm{N}-19)$
II. Anglo-Saxon (N-20 to N-29)
III. Middle English (N-30 to N-49)
IV. Drama and Theater (N-50 to N-54)
V. Epic and Romance (N-55 to N-58)
VI. Prose, Prose Fiction, Criticism, and Rhetoric (N-60 to N-65)
VII. Medieval Latin (N-70 to N-79)

Section $O$ LITERATURE OF THE RENAISSANCE AND EARLIER SEVENTEENTH CENTURY
I. General (O-2 to O-19)
II. Poetry (0-21 to 0-28)
III. Drama and Theater (O-30 to O-39)
IV. Shakespeare (0-40 to 0-59)
V. Prose and Prose Fiction (0-61 to 0-67)
VI. Neo-Latin Studies (O-70 to O-79)

Section P LITERATURE OF THE RESTORATION AND EIGHTEENTH CENTURY
I General (P-3 to P-19)
II. Poetry (P-20 to P-25)
III. Drama and Theater ( $P-30$ to $P-35)$
IV. Prose Fiction ( $P-40$ to $P-49)$
V. Prose and Criticism (P-50)

Section Q LITERATURE OF THE NINETEENTH CENTURY
I. General ( $Q-5$ to $Q-19)$
II. The Romantic Movement (Q-20 to Q-29)
III. The Victorians ( $Q-30$ to $Q-49)$
IV. Poetry (Q-52 to $Q-55)$
V. Drama and Theater (Q-60 to Q-62)
VI. Prose Fiction (Q-73 to Q-77)
VII. Prose and Criticism (Q-80)

\section{Section $R$ LITERATURE OF THE TWENTIETH CENTURY}
I. Age of Transition (R-1 to R-2)
II. General Bibliographies and Guides (R-4 to $R-19)$
III. Biobibliographies and Handbooks (R-21 to R-29)
IV. Poetry (R-30 to R-37)
V. Drama and Theater $(R-40$ to $R-49)$
VI. Prose Fiction (R-50 to $R-59$ )
VII. Prose and Criticism (R-60 to R-62)

\section{Section S AMERICAN LITERATURE}
1. Bibliographies and Guides (S-1 to S-19)
II. Biobibliographies and Reviews of Research (S-20 to S-29)
III. Literary Histories (S-30 to S-38)
IV. Handbooks and Reader's Encyclopedias (S -40 to $S-48$ )
V. Individual Authors (S-50 to S-55)
VI. Poetry (S-63 to S-68)
VII. Drama and Theater (S-70 to S-79) 
VIII. Prose Fiction (S-80 to S-89)

IX. Prose and Criticism (S-92 to S-94)

X. Local and Regional Literature (S-100 to S-119)

XI. Ethnic American Languages and Literatures (S-120 to S-179)

\section{Section T POETRY AND VERSIFICATION}

I. Bibliographies, Bibliographical Guides, and Biobibliographies (T-1 to T-8)

II. Verse and Song Indexes (T-10 to T-18)

III. Anthologies and Collections-Bibliographies and Indexes (T-20 to T-28)

IV. Indexes of Explication and Checklists of Criticism (T-30 to T-35)

V. Histories of English or American Poetry (T-40 to $T-49)$

V. The Language of Poetry (T-50 to T-59)

VII. Prosody and Versification (T-60 to T-69)

VIII. Special Subjects-Bibliographies and Indexes (T-70 to T-89)

\section{Section $U$ THE PERFORMING ARTS-THEATER, DRAMA, AND FLM}

I. Performing Arts and Theater Bibliographies (U-1 to U-19)

II. Handbooks and Reader's Encyclopedias (U-20 to U-29)

III. Catalogs of Major Theater and Drama Collections (U-30 to U-34)

IV. Annals, Checklists, and Indexes to Plays in Anthologies and Collections (U-35 to U-49)

V. Bibliographies and Checklists of Criticism (U-50 to U-59)

VI. Bibliographies and Checklists Concerning Particular Dramatic Genres (U-60 to U-69)

VII. Histories of the Drama and the Theater (U-70 to U-80)

VIII. Film-Bibliographies and Guides (U-83 to U-99)

IX. Film-Handbooks and Encyclopedias (U-100 to U-109)

X. Film-Filmographies, Checklists, and Catalogs (U-110 to U-118)

XI. Film-Indexes and Checklists of Film Literature (U-121 to U-129)

\section{Section W PROSE FICTION AND NONFICTIONAL PROSE}

I. Bibliographies - Prose Fiction (W-1 to W-9)

II. Checklists of Prose Fiction (W-10 to W-15)

III. Handbooks, Guides, and Indexes (W-20 to W-29)

IV. Checklists of Criticism (W-30 to W-37)

V. Histories of the Novel (W-40 to W-49)

VI. Short Fiction (W-50 to W-59)

VII. The Picaresque (W-60 to W-69)

VIII. Gothic Fiction (W-70 to W-79)

IX. Historical Fiction (W-80 to W-89)

X. Detective Fiction (W-90 to W-99)

XI. Fantasy, Utopian Fiction, and Science Fiction (W-100 to W-119)

XII. Nonfictional Prose (W-120 to W-129)

XIII. The Sermon, the Character, and the Essay (W-130 to W-134)

XIV. Travel Literature (W-135 to $W-139$ )

XV. Life Writing (W-141 to W-149)

XVI. Humor and Satire (W-150 to W-159)

\section{Section X THEORY, RHETORIC, AND COMPOSITION}

I. Literary Criticism and Literary Theory before ca. 1950 (X-1 to X-14)

II. Literary Criticism and Literary Theory after ca. 1950 (X-15 to X-29)

III. Literature and the Other Arts and Sciences (X-30 to X-99)

IV. Rhetoric, Communications, and Discourse Theory (X-100 to $X-129)$

V. Style and Stylistics (X-130 to X-139)

VI. Composition and the Teaching of Writing (X-140 to $\mathrm{X}-165)$ 


\section{Section Y BIBLIOGRAPHY}

I. General Bibliographies and Guides (Y-1 to $Y-19)$

II. Analytical and Descriptive Bibliography and Textual Criticism-Basic Works of Reference (Y-20 to Y-39)

III. The History of Printing and the Book Trade ( $Y-40$ to $Y-59)$

IV. Rare and Used Book Trado-Catalogs and Sale Records (Y-60 to Y-79)

V. Book Collecting ( $Y-80$ to $Y-89)$

VI. Libraries and Librarianship (Y-90 to Y-99)

\section{Section Z THE PROFESSION OF ENGLISH}

I. English Studies (Z-1 to Z-19)

II. Directories of Scholars (Z-20 to Z-29)

III. Purposes and Methods of Literary Scholarship (Z-30 to Z-39)

IV. Guides to Research (Z-40 to Z-49)

V. Methods and Techniques (Z-50 to Z-69)

VI. Computer-based Research (Z-70 to Z-79)

VII. Grants and Fellowships (Z-80 to Z-89)

VII. Scholarly Writing (Z-90 to Z-99)

IX. Scholarly Publishing (Z-100 to Z-109)

X. The Academic Job Market (Z-110 to Z-119)

XI. Pedagogy (Z-120 to Z-139)

XII. Alternative Careers (Z-140 to Z-149)

XIII. Keeping Current (Z-150 to Z-159) 